Article

\title{
Growth Responses and Root Characteristics of Lettuce Grown in Aeroponics, Hydroponics, and Substrate Culture
}

\author{
Qiansheng $\mathrm{Li}^{1}{ }^{1}$, Xiaoqiang $\mathrm{Li}^{2}$, Bin Tang ${ }^{3}$ and Mengmeng Gu ${ }^{1, * \mathbb{C}}$ \\ 1 Department of Horticultural Sciences, Texas A \& M AgriLife Extension Service, Texas A \& M University, \\ College Station, TX 77843, USA; qianshengli@tamu.edu \\ 2 Shanghai Jieyou Agriculture Sci \& Tech Co., Ltd., Shanghai 201210, China; xq1992@126.com \\ 3 Spraying Systems (Shanghai) Co., Shanghai 201611, China; billtb@spray.com.cn \\ * Correspondence: mgu@tamu.edu; Tel.: +1-979-845-8567
}

Received: 4 September 2018; Accepted: 16 October 2018; Published: 24 October 2018

\begin{abstract}
Aeroponics is a relatively new soilless culture technology which may produce food in space-limited cities or on non-arable land with high water-use efficiency. The shoot and root growth, root characteristics, and mineral content of two lettuce cultivars were measured in aeroponics, and compared with hydroponics and substrate culture. The results showed that aeroponics remarkably improved root growth with a significantly greater root biomass, root/shoot ratio, and greater total root length, root area, and root volume. However, the greater root growth did not lead to greater shoot growth compared with hydroponics, due to the limited availability of nutrients and water. It was concluded that aeroponics systems may be better for high value true root crop production. Further research is necessary to determine the suitable pressure, droplet size, and misting interval in order to improve the continuous availability of nutrients and water in aeroponics, if it is to be used to grow crops such as lettuce for harvesting above-ground parts.
\end{abstract}

Keywords: soilless culture; root growth; root/shoot ratio

\section{Introduction}

Soilless culture, including aeroponics, aquaponics, and hydroponics, is considered one of the more innovative agricultural strategies to produce more from less, in order to feed the estimated 11 billion people in the world by 2100 [1]. Aeroponics is a promising technology that grows plants with their root systems exposed to a nutrient mist in a closed chamber [2]. Plants grow well in aeroponics, primarily because of the highly aerobic environment it creates. It is even possible to control the root-zone atmosphere when it is combined with a gas delivery system [3]. Integrated vertical aeroponic farming systems with manipulation of temperature and $\mathrm{CO}_{2}$ in the root-zone environment can achieve more efficient use of land area to secure a vegetable supply in space-limited cities [4]. Aeroponics is also an excellent option for space mission life support systems that require optimum control of growth parameters [5].

Aeroponics has been widely used in plant physiology research, but is not as commonly used as hydroponic methods on a commercial scale [6]. However, aeroponics has been increasingly used for growing numerous vegetable crops such as lettuce, cucumber, melon, tomato, herbs, potato, and floral crops, and especially for those crops where roots are harvested as the end product. Seed potato production may be the most successful application of aeroponics on a commercial scale, done mostly in China, Korea, South America, and African countries in recent years [7-10]. Aeroponics is able to produce large numbers of minitubers in one generation that can be harvested sequentially, eliminating the need for field production, thereby reducing costs and saving time [7]. This technique was applied 
to effectively produce minitubers of yam (Dioscorea rotundata and D. alata) in Nigeria and Ghana [11,12]. Aeroponics could be an alternative production system for other high-value root and rhizome crops, such as great burdock (Arctium lappa) [13], ginger (Zingiber officinale) [14], medicinal crops, such as Urtica dioica and Anemopsis californica [15] and saffron (Crocus sativus) [16]. Essential oil production of herbs like valerian (Valeriana officinalis) grown using aeroponics has also been reported [17]. Aeroponics has also been reported as an economic method for rapid root induction and clonal propagation of three endangered and medicinally important plants [18]. Aeroponics was used to produce tree saplings (Acacia mangium) with arbuscular mycorrhiza (AM) fungi inoculation [19]. The well-aerated root environment of aeroponics was beneficial for root initiation and subsequent root growth in woody (Ficus) and herbaceous (Chrysanthemum) cuttings [20].

Many studies have clearly shown that aeroponics promotes plant growth rates through optimization of root aeration because the plant is totally suspended in air, giving the plant stem and root systems access to $100 \%$ of the available oxygen in the air [7]. Droplet size and frequency of exposure of the roots to the nutrient solution are the critical factors which may affect oxygen availability [2]. Large droplets lead to less oxygen being available to the root system, while fine droplets produce excessive root hair without developing a lateral root system for sustained growth [10]. Three broad categories are generally used to classify droplet forming systems and droplet size; regular spray nozzles with droplet size $>100 \mu \mathrm{m}$ (spray), compressed gas atomizers with droplet size between 1 to $100 \mu \mathrm{m}$ (fog), and ultrasonic systems with droplet size 1 to $35 \mu \mathrm{m}$ (mist) [21]. The most common type is when the nutrient solution is compressed through nozzles by a high pressure pump, forming a fine mist in the growth chambers [7]. An ultrasonic misting system was adopted in a sterile aeroponics culture system for in vitro propagation [22].

In this study, air atomizing nozzles (1/4J Series) were employed for the aeroponics system. The air atomizing nozzles require a single air source for atomizing the air and to provide independent control of liquid, atomizing air, and fan air pressure for fine tuning of the flow rate, droplet size, spray distribution, and coverage. These air atomizing nozzles were equipped with clean-out needles to eliminate clogging and ensure optimum performance. The objectives of the present study were to compare shoot and root growth, root characteristics, and mineral contents of two lettuce cultivars grown in aeroponics, hydroponics (nutrient film technique, NFT) and substrate culture.

\section{Materials and Methods}

\subsection{Cultivation Systems}

The experiment was carried out in a $12.8 \times 24 \mathrm{~m}$ experimental Venlo type glasshouse, which was equipped with outside and inside shade nets, fans and pad, and misting system. The aeroponics units were built in an A-frame shape, $1.4 \mathrm{~m}$ wide, $1.4 \mathrm{~m}$ high, and $6 \mathrm{~m}$ long; both sides were covered with multiple Styrofoam panels at $60^{\circ}$ angles. The planting density was 25 plants per $\mathrm{m}^{2}$ at a spacing of $20 \times 20 \mathrm{~cm}$. Six nozzles (AEROJSUMAX-6SS, Spraying Systems (Shanghai) Co., Shanghai, China) were placed horizontally at the end and middle of the A-frame. The nozzles can be operated under an air pressure from $0.7 \times 10^{5}$ to $4 \times 10^{5} \mathrm{~Pa}$, with liquid capacity from 7.6 to $63 \mathrm{~L} / \mathrm{h}$. AutoJet ${ }^{\circledR}$ Spray System (Spraying Systems (Shanghai) Co.) and was installed to monitor and automatically adjust the spray pattern, flow rate, droplet size, liquid pressure, and atomizing air pressure. Misting lasted $20 \mathrm{~s}$ with a $30 \mathrm{~s}$ interval before misting again. The droplet size was adjusted to $50 \mu \mathrm{m}$ and the nutrient solution was recycled.

The NFT hydroponics system consisted of a PVC trough on a slope of 1 percent. The trough was $10 \mathrm{~cm}$ wide, $5 \mathrm{~cm}$ deep, and $6 \mathrm{~m}$ long. The cascade troughs were suspended one above the other, up to 7 levels. The nutrient solution entered the high end of the slightly sloping top trough, exited at the low end of that trough into the high end of the next one, and so forth, and back to the reservoir from where it was pumped. The flow rate was set at $5 \mathrm{~L} / \mathrm{min}$. Plants were set $20 \mathrm{~cm}$ apart in each trough.

The substrate culture system was conducted using square PVC plastic pots, which were $46 \mathrm{~cm}$ long, $40 \mathrm{~cm}$ wide, and $18 \mathrm{~cm}$ high. Six plants were planted in each pot at a $20 \times 20 \mathrm{~cm}$ spacing. A mix 
of $50 \%$ peat and $50 \%$ perlite was used as the substrate. The substrate depth was approximately $18 \mathrm{~cm}$. The nutrient solution of $1.2 \mathrm{~L} /$ day was supplied through 3 drip lines in each pot twice a day.

\subsection{Planting and Experimental Arrangement}

Lettuce seeds of cultivars 'Nenglv naiyou' and 'Dasusheng' (Institute of vegetable and flower, CAAS, Beijing, China) were sown in 72-cell polystyrene trays. Each cell was filled with a hydroponic planting basket with a sponge for support. At the two true leaves stage, all plants were watered with a half strength Hoagland's nutrient solution [23] until the seedlings were ready for transplanting. Four weeks after sowing, lettuce seedlings were transplanted to the aeroponics, hydroponics, and substrate culture systems. Plants were supplied with full strength Hoagland's nutrient solution (containing N 210 mg/L, K 235 mg/L, Ca 200 mg/L, P 31 mg/L, S 64 mg/L, Mg 48 mg/L, B 0.5 mg/L, Fe 1 to $5 \mathrm{mg} / \mathrm{L}$, Mn $0.5 \mathrm{mg} / \mathrm{L}, \mathrm{Zn} 0.05 \mathrm{mg} / \mathrm{L}, \mathrm{Cu} 0.02 \mathrm{mg} / \mathrm{L}$, Mo $0.01 \mathrm{mg} / \mathrm{L}$ ). Three A-shape aeroponics units, 12 hydroponic troughs, and 24 substrate culture pots were planted for the comparison experiment.

\subsection{Harvesting and Measurement}

\subsubsection{Biomass and Root/Shoot Ratio}

Nine plants from each cultivation system were harvested and washed with tap water. Substrates in the roots of the plants from the substrate cultivation treatment were gently washed off. The fresh weight of shoots and roots was recorded immediately after removing the free surface moisture with soft paper towels. Shoot and root samples were then oven dried at $85^{\circ} \mathrm{C}$ for $48 \mathrm{~h}$, and weighed for dry weight on a scale accurate to $0.0001 \mathrm{~g}$. The root/shoot ratio was calculated as the root dry weight/shoot dry weight.

\subsubsection{Root Characteristics}

Five plants from each cultivation treatment were randomly sampled for measurement of root characteristics. Washed roots were immersed and spread out in a $40 \times 25 \times 10 \mathrm{~cm}$ square blue plastic container which was filled with tap water to a depth of $3 \mathrm{~cm}$. The entire root system was photographed from above with a digital camera (Nikon D90, Nikon Corporation, Tokyo, Japan) and saved using the jpeg format (Figure 1A). The photographs were re-cropped, scaled (Figure 1B), and processed with GiA Roots software (Georgia Tech Research Corporation and Duke University, USA) to obtain a threshold image (Figure 1C) for measuring the characteristics of all the roots. The measured root characteristics included average root diameter (width), root length (network length), root area (network surface area), root volume (network volume), maximum number of roots, median number of roots, and network perimeter [24].

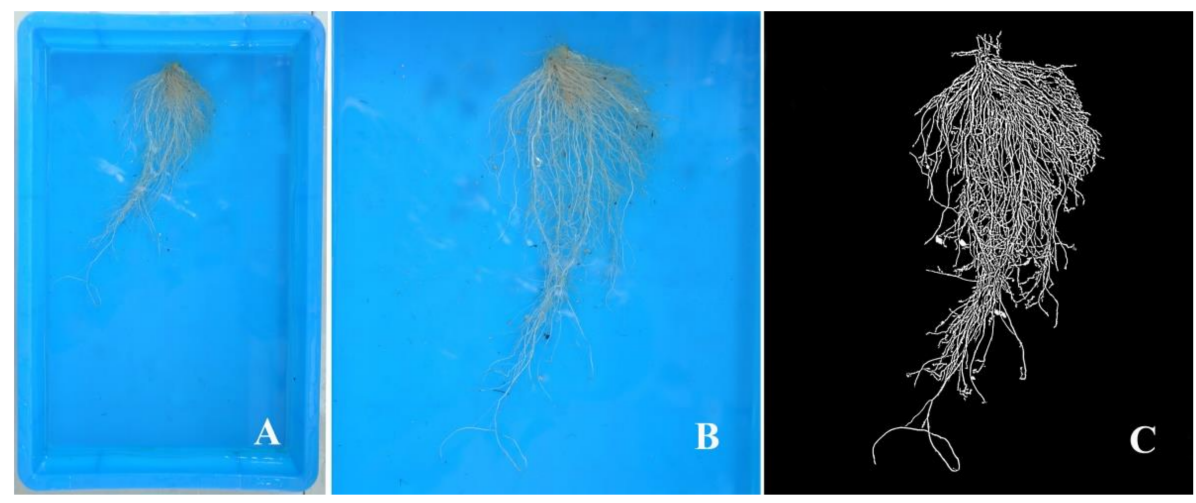

Figure 1. The entire root was immersed and spread out in a $40 \times 25 \times 10 \mathrm{~cm}$ square plastic container filled with tap water to a depth of $3 \mathrm{~cm}$ (A), the image was re-cropped after being scaled (B), and changed to a threshold image (C) with GiA Roots software, for root characteristics measurements. 


\subsubsection{Plant Leaf Nitrogen, Phosphorus, and Potassium Content}

Three plants from each cultivation treatment were randomly sampled for mineral nutrient analysis and oven dried as above. The dried shoots from the different treatments were milled to passed through a $1 \mathrm{~mm}$ screen. The ground dry material ( 0.2000 g) was wet digested using a $\mathrm{H}_{2} \mathrm{SO}_{4}-\mathrm{H}_{2} \mathrm{O}_{2}$ solution. Nitrogen content was determined using the Kjeldahl method [25]. Phosphorus was determined by the ascorbic acid molybdenum blue method [26]. Potassium was determined by flame emission spectrophotometry [27].

\subsection{Statistical Analysis}

All results were subjected to a two-way analysis of variance (ANOVA) using SPSS Statistics 19.0; the effects of the cultivation system, genotypes (cultivars), and their interaction were analyzed. Within each cultivar, means were separated using Duncan's multiple range test at $P=0.05$. The results were expressed as means $\pm \mathrm{SE}$.

\section{Results}

\subsection{Plant Growth and Biomass}

The cultivation systems significantly influenced the growth of both lettuce cultivars. Lettuce grown in hydroponics had larger above-ground parts, while the aeroponic lettuce had greater root dry weight and root/shoot ratio, and plants from substrate cultivation had the smallest size (Figure 2, Table 1).

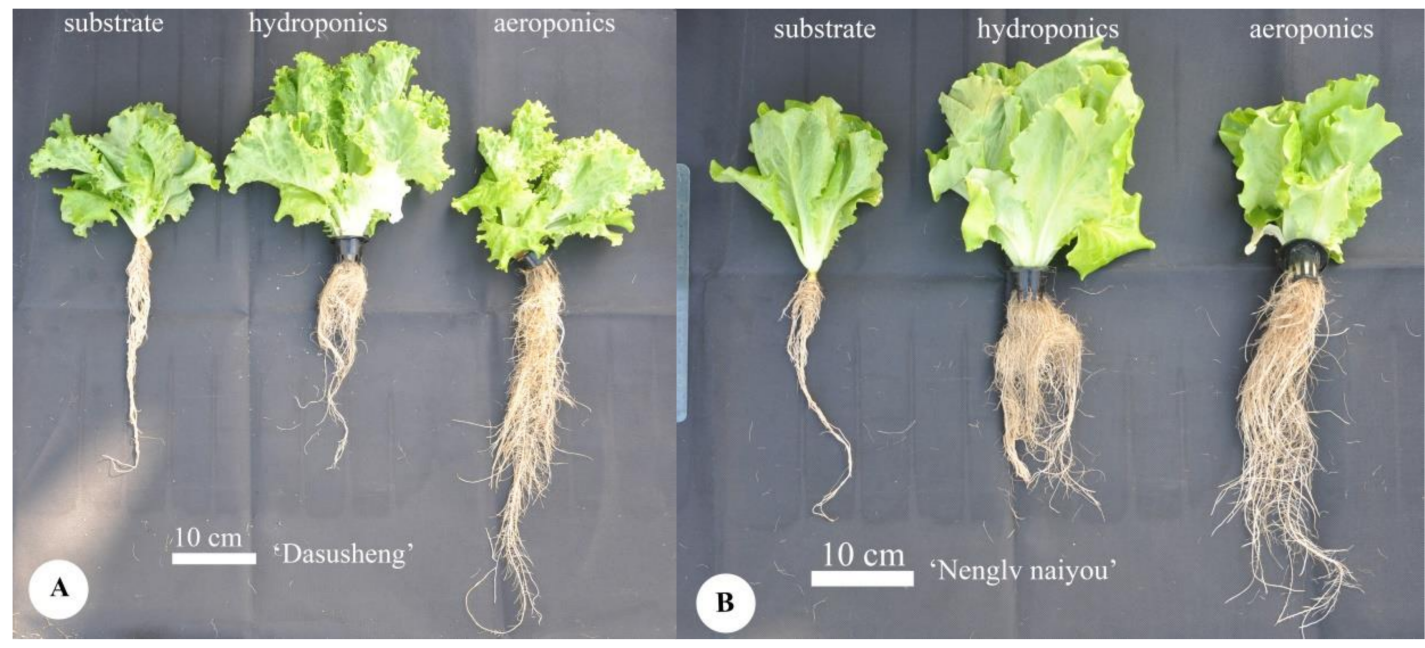

Figure 2. Whole plants of lettuce cultivars 'Dasushen' (A) and 'Nenglv naiyou' (B) 45 days after transplanting in aeroponic, hydroponic, and substrate cultivation systems.

The two-way ANOVA showed significant effects of cultivation system on shoot and root fresh weight, shoot and root dry weight, and root/shoot ratio (Table 1). However, genotype only showed significant effects on shoot and root dry weight. An interaction between cultivation system and genotype was significant on fresh weight and dry weight of shoot and root, but not on the root/shoot ratio.

In both cultivars, the shoot fresh and dry weights of hydroponic lettuce were approximately twice that of aeroponic and substrate cultivated lettuce (Table 1). Root fresh weights of aeroponics and hydroponics lettuce were significantly higher than that of substrate cultivated lettuce. The root dry weights of both cultivars in aeroponics were significantly higher than that of hydroponics and substrate cultivation. The most remarkable difference between the three growing methods was the root/shoot ratio. In both cultivars, the root/shoot ratio of aeroponics lettuce was almost three times 
that of the hydroponics lettuce, and was also significantly higher than that of the substrate culture (Table 1).

Table 1. Shoot and root fresh weight (FW), dry weight (DW), and root to shoot ratio of two lettuce cultivars grown in three cultivation systems.

\begin{tabular}{|c|c|c|c|c|c|}
\hline & Shoot FW (g) & Root FW (g) & Shoot DW (g) & Root DW (g) & Root/Shoot Ratio \\
\hline \multicolumn{6}{|c|}{ Lactuca sativa 'Dasusheng' } \\
\hline aeroponics & $37.8 \pm 2.67^{b z}$ & $8.67 \pm 1.20^{\mathrm{a}}$ & $2.40 \pm 0.17^{\mathrm{b}}$ & $0.80 \pm 0.15^{\mathrm{a}}$ & $0.32 \pm 0.04^{\mathrm{a}}$ \\
\hline hydroponics & $88.8 \pm 9.47^{\mathrm{a}}$ & $8.78 \pm 1.24^{\mathrm{a}}$ & $4.86 \pm 0.54^{\mathrm{a}}$ & $0.59 \pm 0.06^{b}$ & $0.12 \pm 0.01^{\mathrm{c}}$ \\
\hline substrate & $49.2 \pm 2.34^{b}$ & $6.92 \pm 0.43^{b}$ & $3.23 \pm 0.13^{b}$ & $0.69 \pm 0.03^{b}$ & $0.22 \pm 0.02^{b}$ \\
\hline \multicolumn{6}{|c|}{ Lactuca sativa 'Nenglv Naiyou' } \\
\hline aeroponics & $50.9 \pm 2.60^{b}$ & $10.3 \pm 0.46^{\mathrm{a}}$ & $2.58 \pm 0.11^{\mathrm{b}}$ & $0.77 \pm 0.07^{\mathrm{a}}$ & $0.30 \pm 0.03^{a}$ \\
\hline hydroponics & $96.1 \pm 4.23^{\text {a }}$ & $11.5 \pm 1.07^{\mathrm{a}}$ & $4.80 \pm 0.16^{\mathrm{a}}$ & $0.54 \pm 0.03^{b}$ & $0.11 \pm 0.01^{b}$ \\
\hline substrate & $39.4 \pm 1.72^{c}$ & $3.9 \pm 0.35^{b}$ & $2.03 \pm 0.06^{c}$ & $0.26 \pm 0.03^{c}$ & $0.13 \pm 0.01^{b}$ \\
\hline \multicolumn{6}{|c|}{ Significance } \\
\hline Cultivation system (CS) & $* * * y$ & $* * *$ & $* * *$ & ** & $* * *$ \\
\hline Genotype $(\mathrm{G})$ & Ns & Ns & * & * & ns \\
\hline $\mathrm{CS} \times \mathrm{G}$ & * & $* *$ & * & * & $\mathrm{ns}$ \\
\hline
\end{tabular}

${ }^{\mathrm{z}}$ Values are mean $\pm \mathrm{SE}(n=9)$. In the same cultivar, values followed by the same superscript letter are not significantly different $(P \leq 0.05)$. ${ }^{* * *}=P<0.001 ;{ }^{* *}=P<0.01 ;^{*}=P<0.05 ;$ ns, not significant at $P \geq 0.05$.

\subsection{Root Characteristics}

Analysis of the root characteristics by GiA Roots software revealed details of the influence of growing methods on root growth. The root length, area, volume, and network perimeter of aeroponic lettuce (both cultivars) were significantly greater than that of hydroponic and substrate cultivated lettuce (Table 2). In particular, for the cultivar 'Dasusheng', the root length, root area, root volume, and perimeter in aeroponic cultivation were four to five times that of the hydroponic and substrate cultivation. However, the average root diameter did not significantly differ among treatments in the cultivar 'Dasusheng'. Average root diameter of hydroponically-grown 'Nenglv naiyou' was significantly greater than that from substrate cultivation. The maximum and median numbers of roots of aeroponic 'Dasusheng' lettuce were two to three times higher than that from hydroponic and substrate cultivation; such differences in maximum root number were not found for the cultivar 'Nenglv naiyou' where only median root number for aeroponic cultivation was greater than hydroponic but not substrate cultivation.

Table 2. Root characteristics of lettuce grown in aeroponics, hydroponics, and substrate culture systems.

\begin{tabular}{|c|c|c|c|c|c|c|c|}
\hline & $\begin{array}{c}\text { Average Root } \\
\text { Diameter (mm) }\end{array}$ & $\begin{array}{l}\text { Root Length } \\
\text { (cm) }\end{array}$ & $\begin{array}{l}\text { Root Area } \\
\left(\mathrm{cm}^{2}\right)\end{array}$ & $\begin{array}{l}\text { Root Volume } \\
\qquad\left(\mathrm{cm}^{3}\right)\end{array}$ & $\begin{array}{l}\text { Maximum } \\
\text { No. of } \\
\text { Roots }\end{array}$ & $\begin{array}{l}\text { Median No. } \\
\text { of Roots }\end{array}$ & $\begin{array}{l}\text { Network } \\
\text { Perimeter } \\
\text { (cm) }\end{array}$ \\
\hline \multicolumn{8}{|c|}{ Lactuca sativa 'Dasusheng' } \\
\hline aeroponics & $0.501 \pm 0.017 \mathrm{az}$ & $3043 \pm 231^{a}$ & $479 \pm 42^{a}$ & $7.24 \pm 0.77^{\mathrm{a}}$ & $75.0 \pm 5.8^{\mathrm{a}}$ & $39.0 \pm 4.1^{\mathrm{a}}$ & $6019 \pm 473^{a}$ \\
\hline hydroponics & $0.551 \pm 0.025^{\mathrm{a}}$ & $581 \pm 113^{b}$ & $100 \pm 20^{b}$ & $1.64 \pm 0.35^{b}$ & $24.6 \pm 2.9^{b}$ & $13.8 \pm 1.6^{b}$ & $1164 \pm 221^{b}$ \\
\hline substrate & $0.501 \pm 0.007^{\mathrm{a}}$ & $724 \pm 126^{b}$ & $114 \pm 21^{b}$ & $1.67 \pm 0.35^{b}$ & $32.6 \pm 5.3^{b}$ & $17.4 \pm 2.2^{b}$ & $1437 \pm 245^{b}$ \\
\hline hydroponics & $0.554 \pm 0.0009^{a}$ & $1688 \pm 239^{b}$ & $296 \pm 46^{b}$ & $4.91 \pm 0.85^{\mathrm{ab}}$ & $54.4 \pm 3.0^{\mathrm{a}}$ & $19.0 \pm 4.8^{\mathrm{b}}$ & $3379 \pm 473^{b}$ \\
\hline substrate & $0.487 \pm 0.0006^{b}$ & $1378 \pm 58^{b}$ & $211 \pm 10^{b}$ & $2.99 \pm 0.15^{b}$ & $51.2 \pm 1.6^{\mathrm{a}}$ & $37.0 \pm 2.6^{\mathrm{a}}$ & $2755 \pm 113^{b}$ \\
\hline \multicolumn{8}{|c|}{ Significance } \\
\hline Cultivation system (CS) & $\mathrm{ns}^{\mathrm{y}}$ & $* * *$ & $* *$ & $*$ & $* * *$ & $* * *$ & * \\
\hline
\end{tabular}

${ }^{\mathrm{z}}$ Values are mean $\pm \mathrm{SE}(n=9)$. In the same cultivar, values followed by the same superscript letter are not significantly different $(P \leq 0.05) .{ }^{* * *}=P<0.001 ;{ }^{* *}=P<0.01 ;{ }^{*}=P<0.05 ;$ ns, not significant at $P \geq 0.05$. 
The two-way ANOVA indicated that both the cultivation system and genotype significantly affected all the root characteristics except the average root diameter, i.e., average root diameter, root length, median number of roots, and root perimeter (Table 2).

\subsection{Leaf $N, P$, and $K$ Contents}

In both cultivars, the leaf $\mathrm{N}$ content of hydroponic lettuce was significantly higher than that of aeroponic and substrate cultivated lettuce, but there was no difference between aeroponic and substrate cultivation (Figure $3 \mathrm{~A}$ ). The leaf $\mathrm{P}$ content of hydroponic lettuce was significantly higher than that of the aeroponic and substrate cultivated lettuce (Figure 3B). Leaf K content of both aeroponic and hydroponic lettuce was significantly higher than that of substrate cultivated lettuce, but there was no difference between the aeroponic and hydroponic lettuce (Figure 3C).
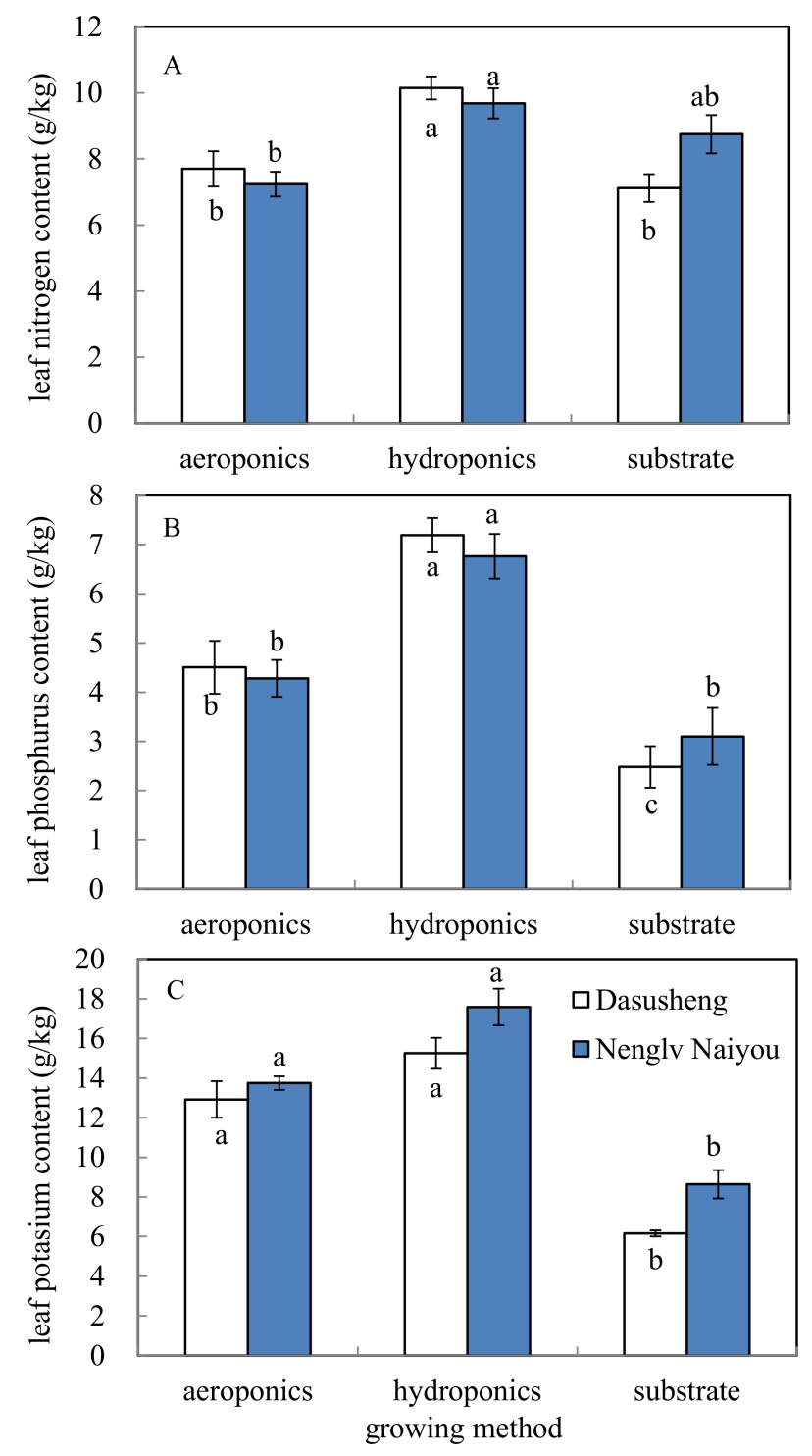

Figure 3. Leaf nitrogen (A), phosphorus (B), and potassium (C) content of two lettuce cultivars grown on aeroponics, hydroponics, and substrate cultivation systems. Values are mean $\pm \mathrm{SE}(n=3)$. In the same cultivar, values followed by the same letter are not significantly different $(P \leq 0.05)$.

The two-way ANOVA indicated that the cultivation system significantly affected leaf N, P, and K contents (Table 3), while genotype only had a significant effect on the leaf $\mathrm{K}$ content, and there was no significant interaction between cultivation system and genotype. 
Table 3. F-values from a two-way analysis of variance (ANOVA) of leaf nitrogen, phosphorus, and potassium content as affected by three cultivation systems and two genotypes.

\begin{tabular}{|c|c|c|c|}
\hline & $\mathbf{N}$ & $\mathbf{P}$ & $\mathbf{K}$ \\
\hline Cultivation system (CS) & $11.6^{* * * \mathrm{z}}$ & $50.6^{* * *}$ & $84.6^{* *}$ \\
\hline Genotype $(\mathrm{G})$ & $0.28^{\mathrm{ns}}$ & $0.01^{\mathrm{ns}}$ & $10.7^{* *}$ \\
\hline $\mathrm{CS} \times \mathrm{G}$ & $2.51^{\mathrm{ns}}$ & $0.88^{\mathrm{ns}}$ & $0.84^{\mathrm{ns}}$ \\
\hline
\end{tabular}

\section{Discussion}

The most impressive result of this study was the significant improvement of root growth of lettuce in the aeroponic system. The cultivation systems also affected the fresh weight, dry weight, and root/shoot ratio, while the genotypes only had significant effects on dry weight, and the interaction between them also significantly affected the biomass but not the root/shoot ratio. In both cultivars, the root dry weight of aeroponic lettuce was significantly higher than that of hydroponic and substrate cultivation, and the root/shoot ratio of aeroponic lettuce was two to three times that of the other two systems. The two-way ANOVA results indicated that the root characteristics were more dependent on genotype; however, the cultivation systems also had significant effects on the root characteristics except on root diameter. The greater total root length, root area, and root volume further proved that aeroponics was beneficial to root growth. However, the greater root system of aeroponics did not lead to more shoot biomass (yield) than hydroponics. Instead, shoot biomass of aeroponic lettuce was significantly less than that of hydroponics. This may be due to sufficient nutrient and water supply when the root system was submerged continuously in nutrient solution. The cultivation systems had significant influences on leaf N, P, and K content, while genotype only showed significant effects on K content, and there was no cultivation system by genotype interaction on the mineral contents.

In aeroponics, the nutrient solution was only sprayed as fine droplets at intervals, which may limit shoot growth and improve root growth, as the plant's response may be to adapt to the relative deficit of water and nutrients during the intervals. In valerian (Valeriana officinalis) cultivation trials, it was also found that both leaf area and biomass production in an aeroponic system were lower than in floating raft hydroponic and substrate cultivation systems; it was concluded that this may be caused by the higher proliferation of roots inside the frame reducing the performance of nozzles [17]. The root number of saffron (Crocus sativus) plants was also significantly greater in aeroponics than that in hydroponics and soil culture, but no significant difference in shoot growth was found [16]. The larger distance between misting sprayers and roots restricted root access to the water micro droplets, resulted in decreasing nutrient availability and absorbance. In this case, plants were forced to compensate by increasing root surface area and weight [28]. Thus, the droplet size and the misting interval will have a great effect on plant growth in aeroponic culture.

Good aeration of the root environment is the most important advantage of aeroponics. Aeroponics significantly improved adventitious root formation in rapid root induction and clonal propagation of three endangered and medicinally important plants over soil grown stem cuttings [18]. Aeroponics showed higher yield and better size distribution in potato minituber production, but growth was influenced by such factors as the genotype, the availability of nutrients, the stretching of the cycle, and the culture density [8]. Higher root vitality of plants was observed in aeroponics and aerohydroponics than that of deep water culture [29]. If the roots of plants in aeroponics can absorb nutrients and water readily, better growth of the above-ground part will result. However, the major disadvantage of aeroponics is the possibility of irreversible damage or complete loss, since there is no substrate at all (neither solid nor water) that could enable the plants to survive in the event of a technical or power failure [7,9]. During our experiment, there was a one-day mechanical breakdown of the aeroponic system, which could also have affected growth. 


\section{Conclusions}

From this study, it can be concluded that aeroponics is beneficial to root growth, with significantly greater root/shoot ratio, root length, root area, and root volume. Thus, an aeroponic system may be superior for producing high value, true root crops, particularly for medicinal plants as suggested by Hayden $[13,15]$. When growing root crops in aeroponics, clean products may be harvested sequentially. To grow crops like lettuce in aeroponics for harvesting above-ground parts, further research is necessary to determine suitable pressure, droplet size, and misting interval in order to improve the continuous availability of nutrients and water so that growth of above-ground parts of plants can be optimized.

Author Contributions: Conceptualization, Q.L.; data curation, Q.L.; formal analysis, Q.L.; investigation, X.L.; methodology, Q.L.; resources, B.T.; supervision, M.G.; writing—original draft, Q.L.; writing—review and editing, M.G.

Funding: This project was funded by Spraying Systems (Shanghai) Co. research project J2017-30.

Acknowledgments: We thank Xue Zhang and Minmin Wan for their help with measurements.

Conflicts of Interest: The authors declare no conflict of interest.

\section{References}

1. Lal, R. Feeding 11 billion on 0.5 billion hectare of area under cereal crops. Food Energy Secur. 2016, 5, $239-251$. [CrossRef]

2. Jones, J.B., Jr. Complete Guide for Growing Plants Hydroponically; CRC Press: Boca Raton, FL, USA, 2014.

3. Kratsch, H.A.; Graves, W.R.; Gladon, R.J. Aeroponic system for control of root-zone atmosphere. Environ. Exp. Bot. 2006, 55, 70-76. [CrossRef]

4. He, J. Farming of Vegetables in Space-Limited Environments. Cosmos 2015, 11, 21-36. [CrossRef]

5. Clawson, J.; Hoehn, A.; Stodieck, L.; Todd, P.; Stoner, R. Re-Examining Aeroponics for Spaceflight Plant Growth; SAE Technical Paper 0148-7191; SAE International: Warrendale, PA, USA, 2000.

6. Resh, H.M. Hydroponic Food Production: A Definitive Guidebook for the Advanced Home Gardener and the Commercial Hydroponic Grower; CRC Press: Boca Raton, FL, USA, 2012.

7. Buckseth, T.; Sharma, A.K.; Pandey, K.K.; Singh, B.P.; Muthuraj, R. Methods of pre-basic seed potato production with special reference to aeroponics-A review. Sci. Hortic. 2016, 204, 79-87. [CrossRef]

8. Tierno, R.; Carrasco, A.; Ritter, E.; de Galarreta, J.I.R. Differential Growth Response and Minituber Production of Three Potato Cultivars Under Aeroponics and Greenhouse Bed Culture. Am. J. Potato Res. 2013, 91, 346-353. [CrossRef]

9. Mateus-Rodriguez, J.R.; de Haan, S.; Andrade-Piedra, J.L.; Maldonado, L.; Hareau, G.; Barker, I.; Chuquillanqui, C.; Otazú, V.; Frisancho, R.; Bastos, C.; et al. Technical and Economic Analysis of Aeroponics and other Systems for Potato Mini-Tuber Production in Latin America. Am. J. Potato Res. 2013, 90, 357-368. [CrossRef]

10. Margaret, C. Potential of aeroponics system in the production of quality potato (Solanum tuberosum L.) seed in developing countries. Afr. J. Biotechnol. 2012, 11, 3993-3999.

11. Oteng-Darko, P.; Kyei-Baffour, N.; Otoo, E.; Agyare, W.A. Growing Seed Yams in the Air: The Agronomic Performance of Two Aeroponics Systems Developed in Ghana. Sustain. Agric. Res. 2017, 6, 106-116. [CrossRef]

12. Maroya, N.; Balogun, M.; Asiedu, R.; Aighewi, B.; Kumar, P.L.; Augusto, J. Yam propagation using aeroponics technology. Annu. Res. Rev. Biol. 2014, 4, 3894-3903. [CrossRef]

13. Hayden, A.; Yokelsen, T.; Giacomelli, G.; Hoffmann, J. Aeroponics: An alternative production system for high-value root crops. Acta Hortic. 2004, 629, 207-213. [CrossRef]

14. Hayden, A.L.; Brigham, L.A.; Giacomelli, G.A. Aeroponic cultivation of ginger (Zingiber officinale) rhizomes. Acta Hortic. 2004, 659, 397-402. [CrossRef]

15. Hayden, A.L. Aeroponic and hydroponic systems for medicinal herb, rhizome, and root crops. Hortscience 2006, 41, 536-538.

16. Souret, F.F.; Weathers, P.J. The Growth of Saffron (Crocus sativus L.) in Aeroponics and Hydroponics. J. Herbs Spices Med. Plants 2000, 7, 25-35. [CrossRef] 
17. Tabatabaei, S.J. Effects of Cultivation Systems on the Growth, and Essential Oil Content and Composition of Valerian. J. Herbs Spices Med. Plants 2008, 14, 54-67. [CrossRef]

18. Mehandru, P.; Shekhawat, N.S.; Rai, M.K.; Kataria, V.; Gehlot, H.S. Evaluation of aeroponics for clonal propagation of Caralluma edulis, Leptadenia reticulata and Tylophora indica-Three threatened medicinal Asclepiads. Physiol. Mol. Biol. Plants 2014, 20, 365-373. [CrossRef] [PubMed]

19. Martin-Laurent, F.; Lee, S.-K.; Tham, F.-Y.; Jie, H.; Diem, H.G. Aeroponic production of Acacia mangium saplings inoculated with AM fungi for reforestation in the tropics. For. Ecol. Manag. 1999, 122, $199-207$. [CrossRef]

20. Soffer, H.; Burger, D.W. Effects of dissolved oxygen concentrations in aero-hydroponics on the formation and growth of adventitious roots. J. Am. Soc. Hortic. Sci. 1988, 113, 218-221.

21. Weathers, P.; Liu, C.; Towler, M.; Wyslouzil, B. Mist reactors: Principles, comparison of various systems, and case studies. Electron. J. Integr. Biosci. 2008, 3, 29-37.

22. Tisserat, B.; Jones, D.; Galletta, P.D. Construction and use of an inexpensive in vitro ultrasonic misting system. HortTechnology 1993, 3, 75-78.

23. Hoagland, D.R.; Arnon, D.I. The Water-Culture Method for Growing Plants without Soil, 2nd ed.; Circular 347; California Agricultural Experiment Station: Berkeley, CA, USA, 1950.

24. Galkovskyi, T.; Mileyko, Y.; Bucksch, A.; Moore, B.; Symonova, O.; Price, C.A.; Topp, C.N.; Iyer-Pascuzzi, A.S.; Zurek, P.R.; Fang, S. GiA Roots: Software for the high throughput analysis of plant root system architecture. BMC Plant Biol. 2012, 12, 116. [CrossRef] [PubMed]

25. Horneck, D.A.; Miller, R.O. Determination of total nitrogen in plant tissue. In Handbook of Reference Methods for Plant Analysis; Kalra, Y.P., Ed.; CRC Press LLC: Boca Raton, FL, USA, 1998; pp. 75-83.

26. Jones, J.B., Jr. Laboratory Guide for Conducting Soil Tests and Plant Analysis; CRC Press: Boca Raton, FL, USA, 2001.

27. Horneck, D.; Hanson, D. Determination of potassium and sodium by flame emission spectrophotometry. In Handbook of Reference Methods for Plant Analysis; Kalra, Y.P., Ed.; CRC Press LLC: Boca Raton, FL, USA, 1998; pp. 153-155.

28. Salachas, G.; Savvas, D.; Argyropoulou, K.; Tarantillis, P.; Kapotis, G. Yield and nutritional quality of aeroponically cultivated basil as affected by the available root-zone volume. Emir. J. Food Agric. 2015, 27, 911-918. [CrossRef]

29. Chang, D.C.; Park, C.S.; Kim, S.Y.; Lee, Y.B. Growth and Tuberization of Hydroponically Grown Potatoes. Potato Res. 2012, 55, 69-81. [CrossRef] 